\title{
Practice and Evaluation of Nursing Curriculum Teaching Reform Under the "Curriculum Ideology and Politics" Educational Concept
}

\author{
Rui Zhu', * \\ ${ }^{1}$ Hubei Three Gorges Polytechnic, Yichang, 443000, China \\ *Corresponding author.Email: 278474328@qq.com
}

\begin{abstract}
Taking the nursing curriculum as an example, the teaching reform and effect based on the "curriculum ideology and politics" educational concept was discussed. Students from class 1-2 of 2018 and 2019 nursing major in a college were selected as research objects. 82 vocational college students from class 2019 were selected as test group, and 76 vocational college students from class 2018 were selected as the control group. The control group adopted the traditional teaching method, and the test group adopted the "curriculum ideology and politics" educational concept, integrating ideological and political elements into the specific teaching and conducting an integrated "curriculum ideology and politics" design for each class hour. After the course, students from the two groups were tested for theory, practice and humanistic care ability. The results showed that the theory and practice assessment and humanistic care ability evaluation scores of the test group were higher than those of the control group, and the differences between the two groups were statistically significant. Therefore, the reform of nursing curriculum teaching based on the "curriculum ideology and politics" educational concept would enable students to better master professional theory and practice and enhance students' humanistic care ability. The coordinated promotion of ideological and political education and professional education is worth popularizing.
\end{abstract}

Keywords: Curriculum ideology and politics, Nursing, Professional curriculum, Teaching reform, Practice;

\section{Evaluation}

\section{INTRODUCTION}

$\mathrm{Xi}$ Jinping emphasized at the national conference on ideological and political work in colleges and universities that "classroom teaching should be well used as the main channel, and various curriculum and ideological and political curriculum should work in the same direction to form synergistic effects" [1]. It brought new enlightenment for integrating ideological and political education into nursing professional curriculum [2]. Curriculum ideological and political nursing, with professional curriculum as the carrier and ideological and political concepts as the main concept, realize the unity of knowledge transfer and value guidance in professional curriculum [3]. Patriotism education and vocational education are organically combined. While imparting knowledge, they carry out value guidance, and finally realize classroom education and moral cultivation. In recent years, colleges and universities across the country are actively carrying out the "curriculum ideology and politics" construction. Relatively speaking, the construction of vocational colleges is relatively weak, and there are few empirical studies. Professional teachers generally have problems such as insufficient ideological and political education ability, deficient integrated design of professional talent training objectives, insufficient ideological and political education resources, etc. At the end of 2018, the school launched the "curriculum ideology and politics" education and teaching reform, and the nursing major took the lead in the trial. Starting with the construction of "curriculum ideology and politics" demonstration course or class, the integrated ideological and political design in each class and the whole process has achieved certain results. Taking the "adult nursing" course as an example, this work aims to explore the coordinated promotion between ideological and political education and professional education by deeply excavating and refining the ideological and political elements and moral education functions contained in clinical and classroom under the "curriculum ideology and politics" concept. Students are trained with rich nursing knowledge and exquisite nursing skills. Also, they are cultivated by professional spirit of "protecting life, saving the dead and healing the wounded, willing to contribute and boundless love". The classroom should really become an educational position of "preaching, teaching and dispelling doubts". It is necessary to construct the ideological and political work pattern of all staff, whole process and all-round education, and provide a theoretical basis for improving the examination results and humanistic care ability of nursing students. 


\section{OBJECTS AND METHODS}

\subsection{Objects}

Students from class 1-2 of 2018 and 2019 nursing major in a college were selected as research objects. 82 vocational college students from class 2019 were selected as test group, including 1 male and 81 female, aged from 19 to 22 . 76 vocational college students from class 2018 were selected as control group, including 7 male and 69 female, aged from 19 to 22 . Both groups had the same curriculum and teachers. There was no significant difference between the two groups with regard to age, gender and daily performance $(P>0.05)$, which met the basic research requirements.

\subsection{Methods}

\subsubsection{Teaching method}

(1) Control group. The control group adopted the traditional teaching mode, mainly explaining the relevant teaching content, and the students mainly listened. (2) Test group. Based on the "curriculum ideology and politics" educational concept, the test group integrated ideological and political elements into teaching and designed an integrated "curriculum ideology and politics" for each course. The following takes the course "nursing of patients with acute myocardial infarction" as an example (see Table $1)$.

Table 1. Curriculum ideological and political teaching design of "nursing of patients with acute myocardial infarction"

\begin{tabular}{|c|c|c|c|c|}
\hline Step link & Teaching content & Ideological and political mapping & Integration method & $\begin{array}{l}\text { Time } \\
\text { (min) }\end{array}$ \\
\hline $\begin{array}{l}\text { Classroom } \\
\text { organization }\end{array}$ & $\begin{array}{l}\text { Prepare for class (environment, } \\
\text { items, self), check attendance }\end{array}$ & $\begin{array}{l}\text { Professional environment, nurses appearance } \\
\text { standards, compliance and punctuality }\end{array}$ & $\begin{array}{l}\begin{array}{l}\text { Teachers practice and } \\
\text { create environmental } \\
\text { atmosphere }\end{array} \\
\end{array}$ & 1 \\
\hline $\begin{array}{l}\text { Pre-class task } \\
\text { inspection }\end{array}$ & $\begin{array}{l}\text { Check the effect of "race for life } \\
\text { and death - myocardial infarction } \\
\text { first aid record" before class }\end{array}$ & "Time is life" first aid concept & $\begin{array}{l}\text { Key word cloud, } \\
\text { discussion method }\end{array}$ & 5 \\
\hline Import & $\begin{array}{l}\text { News introduction: Maradona died } \\
\text { of a sudden myocardial infarction; } \\
\text { November } 20 \text { is "China } \\
\text { myocardial infarction treatment } \\
\text { day" }\end{array}$ & $\begin{array}{l}\text { The social responsibility consciousness of "first } \\
\text { witness, on-site first aid", the importance of } \\
\text { equality in front of life and skilled nursing skills; } \\
\text { The ruling idea of "life first" in China }\end{array}$ & $\begin{array}{l}\text { Social hot news } \\
\text { attention, teaching } \\
\text { law }\end{array}$ & 4 \\
\hline \multirow{3}{*}{ New class } & $\begin{array}{l}\text { Typical case analysis of acute } \\
\text { myocardial infarction }\end{array}$ & $\begin{array}{l}\text { Through the phenomenon to see the essence, } \\
\text { specific problems specific analysis; Skill } \\
\text { competition spirit, craftsman spirit }\end{array}$ & $\begin{array}{l}\text { Teaching method, } \\
\text { CBL teaching } \\
\text { method }\end{array}$ & 5 \\
\hline & $\begin{array}{l}\text { Formulate the "nursing of patients } \\
\text { with acute myocardial infarction" } \\
\text { program }\end{array}$ & $\begin{array}{l}\text { Possess holistic nursing concept and systematic } \\
\text { thinking; Analyze the main contradiction and } \\
\text { secondary contradiction; Application of nursing } \\
\text { procedures }\end{array}$ & $\begin{array}{l}\text { Task-driven method, } \\
\text { group team } \\
\text { collaboration }\end{array}$ & 15 \\
\hline & $\begin{array}{l}\text { Implement the "nursing of patients } \\
\text { with acute myocardial infarction" } \\
\text { program }\end{array}$ & $\begin{array}{l}\text { Professional ethics of "love and dedication, saving } \\
\text { the dead and healing the wounded, loving boundless } \\
\text { and treating all alike"; Emotional resonance and } \\
\text { empathy of "what the urgent patient needs"; } \\
\text { Concept of "respecting patients, life first"; Self- } \\
\text { cultivation; Teamwork spirit }\end{array}$ & $\begin{array}{l}\text { SP (standardized } \\
\text { patient) teaching } \\
\text { method, high } \\
\text { simulation scenario } \\
\text { simulation, role } \\
\text { playing }\end{array}$ & 45 \\
\hline $\begin{array}{l}\text { Effect } \\
\text { evaluation }\end{array}$ & $\begin{array}{l}\text { Comments on summary, self- } \\
\text { evaluation, mutual evaluation, } \\
\text { teacher evaluation, "the most } \\
\text { beautiful nurse" selection }\end{array}$ & $\begin{array}{l}\text { Humanistic quality, communication ability, } \\
\text { professional ethics, love and injury concept will be } \\
\text { included in the assessment dimension }\end{array}$ & $\begin{array}{l}\text { Teaching method } \\
\text { refers to the } \\
\text { evaluation form } \\
\text { evaluation, give play } \\
\text { to the assessment and } \\
\text { evaluation baton }\end{array}$ & 10 \\
\hline Expansion & $\begin{array}{l}\text { Local news: new results of } \\
\text { Yichang Central People's Hospital } \\
\text { chest pain center construction in } \\
\text { the treatment of patients with } \\
\text { acute myocardial infarction } \\
\end{array}$ & $\begin{array}{l}\text { Keep learning and progress, absorb the new } \\
\text { knowledge, new technology, new process and new } \\
\text { method of industrial upgrading and industry } \\
\text { development }\end{array}$ & $\begin{array}{l}\text { Combined with the } \\
\text { local hospital } \\
\text { examples, combined } \\
\text { with the internship }\end{array}$ & 4 \\
\hline $\begin{array}{l}\text { Homework } \\
\text { assignment }\end{array}$ & $\begin{array}{l}\text { See the course platform } \\
\text { assignments for details }\end{array}$ & $\begin{array}{l}\text { Rigorous and meticulous, "learn and practice" (the } \\
\text { essence of traditional Chinese culture from the } \\
\text { Analects) }\end{array}$ & $\begin{array}{l}\text { Practice method, } \\
\text { review }\end{array}$ & 1 \\
\hline $\begin{array}{l}\text { Restore training } \\
\text { room }\end{array}$ & $\begin{array}{l}\text { Organize and clean the training } \\
\text { room }\end{array}$ & $\begin{array}{l}\text { Work is the most glorious, cleaning, maintaining, } \\
\text { sorting and placing the training materials, cleaning } \\
\text { and eliminating the training room }\end{array}$ & Labor education & 0 \\
\hline
\end{tabular}




\subsubsection{Evaluation method}

After the course, the theory and operation tests will be conducted. The comprehensive test score $=$ theoretical score $(80 \%)+$ practical training score $(20 \%)$. After the course implementation, a questionnaire was issued. The humanistic care ability scale of nursing college students compiled by Huang Yibing was used to evaluate students' humanistic care ability [4]. The scale includes 8 dimensions: instilling faith and hope, health education, humanistic and altruistic values, scientifically solving health problems, helping to meet basic needs, providing a good environment, promoting emotional communication and helping to relieve difficulties. There are 45 items in total, and each item is scored according to Likert level 5. The forward items from "full compliance" to "full noncompliance" were scored 4-0 points respectively, and the reverse items from "full compliance" to "full noncompliance" were scored $0-4$ points respectively. The Cronbach's a coefficient and content validity of the scale were 0.904 and 0.960 , with good reliability and validity [5]

\subsubsection{Statistical method}

EpiData 3.0 double entry was used to establish the database, and SPSS 19.0 statistical software was imported for analysis. The measurement data were described by mean \pm standard deviation, and t-test was used for inter group comparison. The difference was statistically significant $(\mathrm{P}$ $<0.05)$.

\section{RESULTS AND ANALYSES}

\subsection{Comparison of assessment scores between test and control groups (see Table 2)}

Table 2. Comparison of theoretical and practical test scores between test group and control group

$$
(\overline{\mathrm{X}} \pm S \text {, points })
$$

\begin{tabular}{|c|c|c|c|c|}
\hline & $\begin{array}{c}\text { Test } \\
\text { group }\end{array}$ & $\begin{array}{c}\text { Control } \\
\text { group }\end{array}$ & t & P \\
\hline Theoretical & $78.23 \pm$ & $75.46 \pm$ & 6.623 & $<$ \\
scores & 2.74 & 3.15 & & 0.01 \\
\hline Practical scores & $\begin{array}{c}83.17 \pm \\
3.25\end{array}$ & $\begin{array}{c}81.56 \pm \\
3.42\end{array}$ & 7.258 & $<$ \\
\hline Comprehensive & $\begin{array}{c}85.34 \pm \\
2.68\end{array}$ & $\begin{array}{c}82.73 \pm \\
2.46\end{array}$ & 8.537 & $<$ \\
scores & & & 0.01 \\
\hline
\end{tabular}

Table 2 shows that the theoretical and practical scores in the test group were higher than the control group, and the difference was statistically significant.

\subsection{Comparison of humanistic care ability scores and each dimension scores between test and control groups (see Table 3)}

Table 3. Comparison of humanistic care ability scores between test group and control group $(\overline{\mathrm{X}} \pm S$,

points)

\begin{tabular}{|c|c|c|c|c|}
\hline & $\begin{array}{c}\text { Test } \\
\text { group }\end{array}$ & $\begin{array}{l}\text { Control } \\
\text { group }\end{array}$ & $\mathbf{t}$ & $\mathbf{P}$ \\
\hline $\begin{array}{l}\text { Instill faith and } \\
\text { hope }\end{array}$ & $\begin{array}{c}3.31 \pm \\
0.57\end{array}$ & $\begin{array}{c}3.22 \pm \\
0.57\end{array}$ & 10.762 & $\begin{array}{c}< \\
0.001\end{array}$ \\
\hline Health education & $\begin{array}{c}3.37 \pm \\
0.03 \\
\end{array}$ & $\begin{array}{c}3.28 \pm \\
0.56\end{array}$ & 4.490 & $\begin{array}{c}< \\
0.001 \\
\end{array}$ \\
\hline $\begin{array}{l}\text { Humanistic } \\
\text { altruistic values }\end{array}$ & $\begin{array}{l}3.51 \pm \\
0.03\end{array}$ & $\begin{array}{l}3.25 \pm \\
0.55\end{array}$ & 28.083 & $\begin{array}{c}<< \\
0.001\end{array}$ \\
\hline $\begin{array}{l}\text { Solve health } \\
\text { problems } \\
\text { scientifically }\end{array}$ & $\begin{array}{c}3.26 \pm \\
0.63\end{array}$ & $\begin{array}{c}3.06 \pm \\
0.70\end{array}$ & 25.208 & $\begin{array}{c}< \\
0.001\end{array}$ \\
\hline $\begin{array}{l}\text { Assist in meeting } \\
\text { basic needs }\end{array}$ & $\begin{array}{c}3.39 \pm \\
0.31\end{array}$ & $\begin{array}{c}2.94 \pm \\
0.55\end{array}$ & 15.525 & $\begin{array}{c}< \\
0.001\end{array}$ \\
\hline $\begin{array}{l}\text { Provide a good } \\
\text { environment }\end{array}$ & $\begin{array}{c}1.80 \pm \\
0.06\end{array}$ & $\begin{array}{l}1.61 \pm \\
0.92\end{array}$ & 27.710 & $\begin{array}{c}< \\
0.001\end{array}$ \\
\hline $\begin{array}{l}\text { Promote } \\
\text { emotional } \\
\text { communication }\end{array}$ & $\begin{array}{c}3.31 \pm \\
0.45\end{array}$ & $\begin{array}{c}3.16 \pm \\
0.57\end{array}$ & 11.006 & $\begin{array}{c}< \\
0.001\end{array}$ \\
\hline $\begin{array}{l}\text { Help relieve } \\
\text { difficulties }\end{array}$ & $\begin{array}{c}2.32 \pm \\
0.68\end{array}$ & $\begin{array}{c}2.14 \pm \\
0.79\end{array}$ & 8.465 & $\begin{array}{c}< \\
0.001\end{array}$ \\
\hline $\begin{array}{l}\text { Total amount } \\
\text { table }\end{array}$ & $\begin{array}{c}3.07 \pm \\
0.35 \\
\end{array}$ & $\begin{array}{c}2.89 \pm \\
0.44 \\
\end{array}$ & 23.120 & $\begin{array}{c}< \\
0.001 \\
\end{array}$ \\
\hline
\end{tabular}

It can be seen from Table 3 that students have greatly improved in humanitarian altruistic values, providing good environment and scientific solution of health problems after the "curriculum ideology and politics" implementation. The humanistic care ability scores and each dimension scores in the test group were higher than the control group $(\mathrm{P}<0.05)$.

\section{DISCUSSION}

\subsection{The teaching design and implementation based on the "curriculum ideology and politics" educational concept contributes to strengthening students' theoretical knowledge and improving their skills}

The test group students' theoretical and practical scores were higher than the control group. The reason is that students learn more passively with the traditional teaching mode, focusing on theoretical knowledge teaching and examination point strengthening. It is not conducive to mobilizing students' subjective initiative, and it is difficult 
for students to maintain their attention for a long time [6]. "Curriculum ideology and politics" teaching reflects the student-centered. While paying attention to the acquisition of students' knowledge, it also pays attention to the changes of students' inner feelings. The classroom integrating ideological and political elements are more warm and attractive. Students can intuitively feel the importance of learning professional knowledge and skills. The accumulation of professional knowledge is not accomplished in a day. Only profound nursing knowledge can shoulder the mission of rescuing the dead and healing the wounded. Each nursing technology operation action should be light, stable, accurate and coherent, constantly refined, and can convey emotion through action, showing beauty, concern and a high sense of responsibility.

\subsection{The teaching design and implementation based on the "curriculum ideology and politics" educational concept effectively improve students' humanistic care ability}

Nurses and nursing students should have professional knowledge, health education ability and effective communication ability [7]. Health education encourages people to voluntarily change unhealthy behaviors and related factors affecting health behaviors, eliminate or reduce risk factors affecting health, prevent diseases, promote health and improve quality of life through planned, organized and systematic social and educational activities. Interpersonal communication ability is the guarantee for the smooth and efficient completion of nursing practice. It can be seen from Table 3 that students have greatly improved after the "curriculum ideology and politics" implementation, especially in the aspects of humanistic and altruistic values, providing a good environment, solving health problems scientifically, etc. In the traditional teaching mode, the quality, knowledge and skills taught remain at the conceptual level, and the students lack the guidance from the actual life, personal participation and cognitive level. Through the teaching reform under the "curriculum ideology and politics" educational concept, teachers encourage students to participate in teaching activities, pay attention to current affairs and politics and surrounding news, make good use of the situation, and dissolve the "salt" of "ideological and political elements" into the "soup" of classroom teaching. Students are guided to be firm believers, active communicators and model practitioners of socialist core values, thus cultivating highquality technical and skilled talents with "national feelings, international vision, innovative thinking and craftsman spirit".

\section{3. "Curriculum ideology and politics" is the due meaning of talent training, and the key to its implementation lies in teachers}

On May 28, 2020, the Ministry of Education issued "guidelines for curriculum ideological and political construction in colleges and universities". "The outline" clearly pointed out that comprehensively promoting curriculum ideological and political construction is to implement the fundamental task of moral education strategy. Comprehensively promoting curriculum ideological and political construction is to guide values in knowledge teaching and ability training, and help students shape correct world outlook, outlook on life and values, which is not only the due meaning of talent training, but also the necessary content [8]. The key to implement "curriculum ideology and politics" educational concept, carry out "curriculum ideology and politics" teaching design and implement "curriculum ideology and politics" teaching implementation lies in teachers. It should comprehensively improve teachers' ability of ideological and political education, mobilize all teachers to consciously, efficiently and accurately integrate moral education into the teaching process, and take the initiative to undertake the responsibility of educating people. It means not only to improve teachers' professional level and teaching ability, but also to improve teachers' ideological and political level and curriculum ideological and political ability. Therefore, the school can set up a curriculum ideological and political research center to focus on party construction, publicity, learning and work, youth league committee, educational administration, professional principals, ideological and political teachers and curriculum ideological and political backbone teachers. By holding seminars and report meetings, sharing experiences and resources, and discussing the contents and methods of curriculum ideological and political teaching, it can help teachers improve their ability and solve the puzzles encountered by professional teachers in curriculum ideological and political teaching reform. In the daily training, teachers' awareness and ability of education should be strengthened by inviting relevant experts to give lectures on ideological and political issues, selecting teachers to attend lectures and conducting investigations and studies. Teachers are guided to improve their own political cultivation and selfconsciousness of education and lead students through the selection of teachers' ethics as model, curriculum ideological and political teaching ability competition, curriculum ideological and political teaching research, etc.

\section{CONCLUSION}

The nursing profession serves people and is tasked with promoting health, preventing disease, restoring health and alleviating suffering. Nurses are also the "angels" who accompany people for the longest time. Nursing profession is endowed with the "gene" of ideological and political education, and nursing education is an important part of the 
health care development. In the process of implementing the healthy China strategy, more attention should be paid to the art of healing the wounded and saving the dying, the benevolence with love in mind, solid academic knowledge, the technology with strong skills, and the art of scientific methods by facing the new international situation and the new challenges posed by the epidemic. Carrying out curriculum ideology and politics is an inevitable requirement for training nursing professionals, a correct path to achieve the goal of collaborative education, and an important way to cultivate nursing talents with responsibility to serve people's life and health [9].

\section{ACKNOWLEDGMENT}

This work was supported by Hubei Province education science planning 2020 annual project results (Project No. 2020GB180)

\section{REFERENCES}

[1] Xi Jinping. Xi Jinping on the Governance of China (Volume 2) [M]. Beijing: Foreign Languages Publishing House, 2017.

[2] Li Hui, Qiu Yinling, Zhan Tongxia, et al. Application of Curriculum Ideology and Politics in Simulation of Internal Nursing [J]. Journal of Nursing, 2020, 35 (13): 60-62.
[3] Shi Ruifen. On the Teaching Reform of Nursing Major under the Threshold of "Curriculum Ideology and Politics" [J]. China Nursing Education, 2019, 16 (8): 586-590.

[4] Huang Yibing. Empirical Study on Evaluation of Humanistic Care Ability in Nursing [D]. Fuzhou: Fujian Medical University, 2007.

[5] Huai Panpan, Jin Ruihua, Xue Junlin, et al. Practical Research on Strengthening Care Education in Community Nursing Curriculum [J]. China Nursing Education, 2017, 14 (11): 820-823.

[6] Zhao Mengyuan. Teaching Mode Reform and Practice Based on "Curriculum Ideology and Politics" Taking Geriatric Nursing Curriculum as an Example [J]. Health Vocational Education, 2020, 38 (02): 47-48.

[7] Liu Yilan, Yang Xuejiao, Hu Deying, et al. Advances in Nursing Standards of Humanistic Care [J]. Chinese Journal of Nursing, 2014, 49 (12): 1501-1505.

[8] Wang Lihua. Exploration of "Ideological and Political Curriculum" and "Curriculum Ideology and Politics" in Higher Vocational Colleges [J]. China Vocational and Technical Education, 2019 (18): 71-75.

[9] Wu Junxiao. Exploration and Practice on Ideological and Political Construction of Nursing Curriculum under the Concept of Collaborative Education [J]. Health Vocational Education, 2020, 38 (1): 86-88. 